[JEL Codes: E44, E52]

\title{
Inflation Taxes, Financial Intermediation, and Home Production*
}

\author{
Milton H. Marquis \\ Federal Reserve Bank of San Francisco \\ and \\ Florida State University
}

First Version: November, 2000

This Version: January, 2001

\begin{abstract}
* The author would like to thank Bharat Trehan and Kevin Lansing for helpful discussions, as well as the participants in a seminar at Federal Reserve Bank of San Francisco, where an earlier and substantially different version of this paper was presented. The opinions expressed in this paper are solely those of the author and do not necessarily reflect the views of the Federal Reserve Bank of San Francisco or the Board of Governors of the Federal Reserve System.
\end{abstract}


Abstract: This paper examines the incidence and welfare costs of inflation in the presence of financial market frictions and home production. The results suggest that financing constraints on firms' working capital expenditures significantly increase the welfare costs relative to the standard Cooley-Hansen (1989) cash-in-advance framework. These costs are reduced, but remain above those computed by Cooley and Hansen, when a financial intermediary is introduced that engages in asset transformation by creating liquid, interestbearing deposit accounts and uses the proceeds to finance working capital loans to firms. Explicitly modeling home production activities tends to exacerbate the distortions that inflation induces in employment and market output to a considerable degree, and suggests that the welfare costs of anticipated inflation may be substantially higher than previous estimates. Sensitivity analysis indicates that the magnitude of the market response to inflation and the attendant welfare costs of inflation depend strongly on the elasticity of substitution between capital and labor in home production, and to a much lesser degree on the elasticity of substitution between home and market consumption. When households must also finance their gross investment in home capital by borrowing from the financial intermediary, home production is indirectly taxed by inflation. As a result of this credit friction, resources thus tend to move back into the market, thereby mitigating the adverse effects of inflation on employment and output, while further increasing the welfare losses. [Keywords: Inflation, home production, financial intermediation; EL Codes: E44, E52] 


\section{Introduction}

Early efforts to examine the incidence of anticipated inflation taxes in monetary general equilibrium models concluded that under moderate inflations these taxes have significant, but modest effects on steady-state employment and output and hence on welfare. Money is assumed to be valued as a medium of exchange and enters the models via a cash-inadvance constraint on consumption. ${ }^{1}$ The mechanism that operates in these models is that inflation taxes consumption expenditures and hence the benefits to the household of market activity. As a consequence, this tax reduces consumption and distorts households' resource allocations whereby they withdraw labor services in order to increase leisure, and thus offset somewhat the utility loss associated with lower consumption. The standard references in this literature are to Cooley and Hansen $(1989,1991)$, who find, for example (Table 2, 1989), that an increase in inflation from zero to ten percent reduces steady-state employment by 2.3 percent, reduces steady-state output by 2.4 percent, and lowers welfare by 0.376 percent, where the welfare loss is measured as the percent increase in steadystate consumption under a ten percent inflation rate that would be required to make the household indifferent between the two inflation regimes. ${ }^{2}$

The welfare losses from anticipated inflation can be substantially larger than those measured by Cooley and Hansen if inflation also distorts the required return on capital or

1 Under certain conditions, cash-in-advance on consumption and money-in-the-utility function models are interchangeable.

2 There is a substantial literature that has emerged on the welfare costs of inflation in an endogenous growth context. In a Lucas (1988)-Uzawa (1965) model, Gomme (1993) finds the welfare effects of inflation taxes on consumption to be very small when comparing balanced growth paths. Einarsson and Marquis (1999) find that the transitional dynamics enhance the benefits of disinflation in this model as households reduce employment in order to build up their human capital stock, while the attendant decline in output in the short run is absorbed by lower physical capital investment, thus insulating consumption to some extent. In a Romer (1990) style model with technology spillovers into the payment system, Marquis and Reffett (1994) find much larger welfare costs of inflation as households allocate excessive resources to the payment system at the expense of output. Ireland (1994) finds a similar overinvestment in "financial capital" in an AK-model. Other papers in this literature, not all of which explicitly compute welfare costs, but rather attempt to identify effects of inflation on growth, include Marquis and Reffett (1992,1995), Wang and Yip (1992), DeGregorio (1993), who also provides some cross-country empirical evidence on the negative correlation between growth and inflation, and Chang and Lai (2000). 
labor services. This distortion can occur if firms are required to finance their working capital expenses with short-term nominal debt that must be repaid with current sales revenues. In this case, higher nominal interest rates increase the required productivity of capital and labor and thereby reduce firms' factor demands. ${ }^{3}$ However, the nature of the payment system can also affect those costs. If the borrowed funds arise from intermediated loans, where a portion of the funds are supplied to financial intermediaries by households, say, in return for interest-bearing deposit accounts with high liquidity value, then an increase in inflation would cause households to shift the composition of their media of exchange away from currency and toward bank deposits to insulate themselves partially from inflation with the interest income that they receive on deposits. As a consequence, financial intermediaries can reduce the welfare costs of inflation by providing valued liquidity services in exchange for deposit funds. [see Marquis (1999)].

In addition to examining the above financial market frictions, this paper introduces home production as in Benabib, Rogerson, and Wright (1991) and Greenwood and Hercowitz (1991). Those models give a somewhat symmetric treatment to economic activity at home and in the market. At home, time and "home capital" are used to produce "home consumption" from which households derive utility. While home consumption is unmeasured, data exist to construct time series for the factors of home production. In particular, home capital consists of the stocks of durable consumption goods and housing, which U.S. data indicate are slightly larger in value than market capital, where the latter is measured as the stocks of producer durables, structures, and inventories. Diary data are available, see, e.g. Juster and Stafford (1991), to approximate the allocation of nonmarket time between homework and leisure. Accounting for the additional margins of adjustment available to the household in the home production setting is shown to effect significantly the incidence of inflation on market activities, and on the welfare costs of inflation.

In the presence of home production, the distortions described above cause households to shift resources out of the market sector and into the home sector. Even though home

3 It is noteworthy that a model with this financing constraint and an inelastic labor supply is an isomorphism of the "cash-in-advance on capital" model of Stockman (1981), and in that sense can be seen as a rationalization of his cash constraint on gross investment. 
production is not completely insulated from inflation taxes, since time must be allocated to the market to produce home capital, this model nonetheless suggests that an increase in inflation adversely affects employment and output to a greater extent than is predicted by the standard model without home production. This response is accompanied by an significant increase in measured welfare costs of inflation. ${ }^{4}$ The magnitude of this response is highly sensitive to the intratemporal elasticity of substitution between capital and labor in home production, and much less sensitive to the intratemporal elasticity of substitution between home and market consumption in establishing period utility.

A final version of the model is examined in which households must finance their gross investment in home capital goods with borrowings from the financial intermediary. This credit market friction causes inflation to act as an indirect tax on home production. As a consequence, there is a counter-tendency of higher inflation to discourage the withdrawal of resources from the market for use in home production, and this factor tends to mitigate the adverse effect that is otherwise observed on employment and output, while at the same time reducing welfare.

The home production model where households face financing constraints on gross investment in home capital goods is developed in Section II. In Section III, alternative subsets of this model and their calibrations are presented. These versions of the model are used to examine the importance that various features of the model relating to financial market frictions and home production have separately on both the incidence and the welfare costs of inflation. The distortions created by inflation, and their attendant welfare costs, in the alternative versions of the model are described in Section IV. They suggest that both the credit market frictions and the inclusion of home production increase the welfare costs of anticipated inflation, and that these costs may be substantially higher than has been previously estimated. Section V concludes.

\footnotetext{
4 McGrattan, Rogerson, and Wright (1997) have found a similar large increase in the welfare costs of capital and labor income taxes when home production is explicitly modeled.
} 


\section{A Monetary Home Production Model}

This section develops a monetary model in which households derive utility from leisure and from consumption goods, some of which are purchased in the market and some of which are produced at home. There is a financial intermediary (often referred to as a bank) that raises funds in part by issuing bonds, and in part by offering liquid demand deposit accounts to households. Households use the deposit accounts along with currency holdings to make consumption purchases. Gross investment by households in home capital goods requires financing with bank loans. Time is allocated either to market production, home production, or leisure. Firms rent capital and labor services from the households and finance this working capital with bank loans. Therefore, the credit market frictions that are examined in this paper consist of financing constraints on households' gross investment in home capital goods and on firms' working capital expenses. To model these frictions, firms and households are required to obtain funds for these expenditures by taking out loans with a financial intermediary at the beginning of the period. These loans are then repaid at the end of the period when all financial markets clear.

\section{The household sector}

The representative household maximizes lifetime utility, where period utility is derived from leisure, $n_{t}^{l}$, and from an aggregation of home consumption, $c_{t}^{h}$, and market consumption, $c_{t}^{m}$ given by:

$$
c_{t}^{a}=C\left(c_{t}^{h}, c_{t}^{m}\right)
$$

where: $C: \Re_{+}^{2} \rightarrow \Re_{+}$is the consumption aggregator function that is continuous, and continuously-differentiable in each of its arguments.

The household makes optimal consumption/savings, capital investment, time allocation, and financial asset portfolio allocation decisions given by sequences for home and market consumption and their aggregation, home and market capital, $k_{t+1}^{h}$ and $k_{t+1}^{m}$, labor, $n_{t}^{m}$, time spent in home production, $n_{t}^{h}$, leisure, and the choice of money, $M_{t+1}^{d}$, deposits, 
$D_{t+1}^{d}$, and bonds, $B_{t+1}^{d}$ to carry forward to the next period. It also selects the size of the loan that it takes out from the financial intermediary, $X_{t}^{d}$.

$$
\max _{\left\{c_{t}^{a}, c_{t}^{h}, c_{t}^{m}, n_{t}^{h}, n_{t}^{m}, n_{t}^{l}, k_{t+1}^{h}, k_{t+1}^{m}, M_{t+1}^{d}, D_{t+1}^{d}, B_{t+1}^{d}, X_{t}^{d}\right\}} \sum_{t=0}^{\infty} \beta^{t} U\left(c_{t}^{a}, n_{t}^{l}\right), \quad \beta \in(0,1)
$$

where: $U: \Re_{+}^{2} \rightarrow \Re$ is the current period utility function that is continuous and continuously-differentiable and concave in each of its arguments, and $\beta$ is the household's discount factor.

The household's budget constraint is given by:

$$
\begin{aligned}
& P_{t}\left[c_{t}^{m}+k_{t+1}^{m}-(1-\delta) k_{t}^{m}+k_{t+1}^{h}-(1-\delta) k_{t}^{h}\right]+M_{t+1}^{d}+D_{t+1}^{d}+B_{t+1}^{d}+\left(1+r_{t}^{l}\right) X_{t}^{d} \\
& \leq W_{t} n_{t}^{m}+P_{t} r_{t}^{k} k_{t}^{m}+M_{t}^{d}+\left(1+r_{t}^{d}\right) D_{t}^{d}+\left(1+r_{t}^{b}\right) B_{t}^{d}+X_{t}^{d}+\Pi_{t}^{f}+\Pi_{t}^{c b}, \quad \delta \in(0,1)
\end{aligned}
$$

Sources include: labor income, $W_{t} n_{t}^{m}$, where $W_{t}$ is the nominal wage rate; capital income, $P_{t} r_{t}^{k} k_{t}^{m}$, where $P_{t}$ is the goods price, and $r_{t}^{k}$ is the real rental rate; initial money balances; principal and interest on bank deposits, $\left(1+r_{t}^{d}\right) D_{t}^{d}$, where $r_{t}^{d}$ is the deposit rate; principal and interest on bonds, $\left(1+r_{t}^{b}\right) B_{t}^{d}$, where $r_{t}^{b}$ is the bond rate; the nominal value of loans taken out from the financial intermediary, $X_{t}^{d}$; and per capita dividends from firms, $\Pi_{t}^{f}$, and banks, $\Pi_{t}^{c b}$. Uses are for: nominal consumption and nominal capital investment expenditures, $P_{t}\left[c_{t}^{m}+k_{t+1}^{m}-(1-\delta) k_{t}^{m}+k_{t+1}^{h}-(1-\delta) k_{t}^{h}\right]$, where both capital stocks are assumed to depreciate at the same rate, $\delta$; financial asset holdings, $M_{t+1}^{d}, D_{t+1}^{d}$, and $B_{t+1}^{d}$; and repayment of principle and interest on the loans, $\left(1+r_{t}^{l}\right) X_{t}^{d}$.

Nominal consumption purchases are made in accordance with a payment system technology in which the nominal value of the transactions is constrained by the liquidity available to the household through its money and deposit holdings at the beginning of the period. The specification of this technology is intended to allow for substitutability between money and deposits as media of exchange, while providing a liquidity value to both assets. 


$$
P_{t} c_{t}^{m} \leq \tilde{G}\left(M_{t}^{d}, D_{t}^{d}\right)
$$

where $\tilde{G}: \Re_{+}^{2} \rightarrow \Re_{+}$is the payment system technology function that is increasing and concave in each of its arguments, and homogeneous of degree one in $M_{t}^{d}$ and $D_{t}^{d}$.

The level of home consumption cannot exceed production within the period. The quantity produced is determined by the home production technology, where home capital and time are factor inputs.

$$
c_{t}^{h} \leq H\left(k_{t}^{h}, n_{t}^{h}\right)
$$

where $H: \Re_{+}^{2} \rightarrow \Re_{+}$is the home production function that is continuous, continuouslydifferentiable, and concave in each of its arguments. Gross investment in home capital must be financed by borrowing from the financial intermediary.

$$
P_{t}\left[k_{t+1}^{h}-(1-\delta) k_{t}^{h}\right] \leq X_{t}^{d}
$$

The household also faces a time resource constraint:

$$
n_{t}^{m}+n_{t}^{h}+n_{t}^{l} \leq 1
$$

where total time each period is normalized to one, and a set of non-negativity constraints:

$$
c_{t}^{a}, c_{t}^{h}, c_{t}^{m}, n_{t}^{h}, n_{t}^{m}, n_{t}^{l}, k_{t+1}^{h}, k_{t+1}^{m}, M_{t+1}^{d}, D_{t+1}^{d}, B_{t+1}^{d}, X_{t}^{d} \geq 0
$$

\section{Recursive representation of the household optimization problem}

To set up the problem recursively, the model is first rendered stationary by normalizing nominal variables on bank reserves, whose growth is a source of nonstationarity in the model, and whose role is described more fully below. Let $Z_{t}$ be the nominal supply of bank reserves, and assume that monetary policy is conducted by selecting a rule that governs the growth rate of nominal bank reserves. 


$$
Z_{t+1}=\mu Z_{t}, \quad \mu>\beta \quad \forall t
$$

where $\mu$ is the gross growth rate of bank reserves.

For simplicity, drop the time subscripts and use the prime $\left(^{\prime}\right)$ notation to signify next period's values. Define the following set of normalized variables: $p \equiv P / Z, w \equiv W / Z, m^{d} \equiv$ $M^{d} / Z, d^{d} \equiv D^{d} / Z, b^{d} \equiv B^{d} / Z, x^{d} \equiv X^{d} / Z, \pi^{f} \equiv \Pi^{f} / Z$, and $\pi^{c b} \equiv \Pi^{c b} / Z$. Also define the household's state vector as $s=\left[k^{m}, h^{h}, m^{d}, d^{d}, b^{d}, S\right]$, where $S$ is the aggregate state vector described below. Let $v(s)$ denote the household's value function. The dynamic programming problem becomes:

$$
v(s)=\max _{\gamma(s) \in \Gamma(s)}\left[U\left(c^{a}, n^{l}\right)+\beta v\left(s^{\prime}\right)\right]
$$

where the vector of household decision rules is given by $\gamma(s) \equiv\left[c^{a}(s), c^{m}(s), c^{h}(s), k^{m^{\prime}}(s)\right.$, $\left.k^{h^{\prime}}(s), n^{m}(s), n^{h}(s), n^{l}(s), m^{d^{\prime}}(s), d^{d^{\prime}}(s), b^{d^{\prime}}(s), x^{d}(s)\right]$ and $\Gamma(s)$ is the feasible set of decision rules defined by the following set of normalized constraints, (10)-(15).

$$
\begin{gathered}
c^{a}=C\left(c^{h}, c^{m}\right) \\
p\left[k^{m^{\prime}}-(1-\delta) k^{m}+k^{h^{\prime}}-(1-\delta) k^{h}\right]+\left(m^{d^{\prime}}+d^{d^{\prime}}+b^{d^{\prime}}\right) \mu+\left(1+r^{l}\right) x^{d} \\
\leq w n^{m}+p r^{k} k^{m}+m^{d}+\left(1+r^{d}\right) d^{d}+\left(1+r^{b}\right) b^{d}+x^{d}+\pi^{f}+\pi^{c b} \\
p c^{m} \leq G\left(m^{d}, d^{d}\right) \\
c^{h} \leq H\left(k^{h}, n^{h}\right) \\
p\left[k^{h^{\prime}}-(1-\delta) k^{h}\right] \leq x^{d}
\end{gathered}
$$




$$
n^{m}+n^{h}+n^{l} \leq 1
$$

where $G\left(m^{d}, d^{d}\right) \equiv \tilde{G}\left(M^{d}, D^{d}\right) / Z$ due to its homogeneity properties.

The Euler equations for this model are given below, where the subscripts on the functions $U, C, H$, and $G$ denote partial derivatives.

$$
\begin{gathered}
\beta\left\{U_{n^{\prime \prime}}\left(p^{\prime} / w^{\prime}\right)\left[r^{k^{\prime}}+(1-\delta)\right]\right\}=U_{n^{l}}(p / w) \\
\beta\left\{U_{n^{l^{\prime}}}\left(p^{\prime} / w^{\prime}\right)\left(1+r^{l^{\prime}}\right)(1-\delta)+U_{n^{l^{\prime}}} H_{k^{h^{\prime}}} / H_{n^{h^{\prime}}}\right\}=U_{n^{l}}(p / w)\left(1+r^{l}\right) \\
\left.\beta\left\{\left[U_{n^{l^{\prime}}} / w^{\prime}\right)\right]+G_{m^{d^{\prime}}}\left[\left(U_{c^{a^{\prime}}} C_{c^{m^{\prime}}} / p^{\prime}\right)-\left(U_{n^{l^{\prime}}} / w^{\prime}\right)\right]\right\}=\left(U_{n^{l}} / w\right) \mu \\
\beta\left\{\left[\left(U_{n^{l^{\prime}}} / w^{\prime}\right)\left(1+r^{d^{\prime}}\right)\right]+G_{d^{d^{\prime}}}\left[\left(U_{c^{a \prime}} C_{c^{m^{\prime}}} / p^{\prime}\right)-\left(U_{n^{\prime}} / w^{\prime}\right)\right]\right\}=\left(U_{n^{l}} / w\right) \mu \\
\beta\left\{\left(U_{n^{l^{\prime}}} / w^{\prime}\right)\left(1+r^{b^{\prime}}\right)\right\}=\left(U_{n^{l}} / w\right) \mu \\
U_{n^{l}}=U_{c^{a}} C_{c^{h}} H_{n^{h}}
\end{gathered}
$$

Equations (16) through (20) are efficiency conditions that have the interpretation that the marginal cost to the household, say, of reducing home production time by one unit in the current period in order to increase market production time, is just equal to the marginal benefit, when the additional labor income from the current period is carried forward in the form of market capital, equation (16), home capital, equation (17), money, equation (18), deposits, equation (19), and bonds, equation (20). Equation (21) is the marginal decision to allocate nonmarket time between homework and leisure.

\section{The firm sector}

The firm sector is assumed to be perfectly competitive and is modeled as a single aggregate firm that maximizes per capita profits, denoted $\Pi_{t}^{f}$, period-by-period. The firm 
owns the production technology, chooses the per capita quantities of factor inputs of market capital, $k_{t}^{m d}$, and labor, $n_{t}^{m d}$, and the amount of per capita loans, $V_{t}^{d}$, that it obtains from the financial intermediary to finance its working capital. These loans are taken out at the beginning of the period and are repaid at the end of the period.

The firm's optimization problem becomes:

$$
\max _{\left\{k_{t}^{m d}, n_{t}^{m d}, V_{t}^{d}\right\}} \Pi_{t}^{f}
$$

where period profits are given by revenues, $P_{t} y_{t}$, with $y_{t}$ denoting the firm's per capita output, less repayment of principal and interest on the loans in the amount, $\left(1+r_{t}^{l}\right) V_{t}^{d}$, or

$$
\Pi_{t}^{f}=P_{t} y_{t}-\left(1+r_{t}^{l}\right) V_{t}^{d}
$$

Output is determined by the production technology.

$$
y_{t}=F\left(k_{t}^{m d}, n_{t}^{m d}\right)
$$

where $F: \Re_{+}^{2} \rightarrow \Re_{+}$is the production function that is continuous, continuously-differentiable, and concave in each of its arguments.

The financing constraint is given by:

$$
W_{t} n_{t}^{m d}+P_{t} r_{t}^{k} k_{t}^{m d} \leq V_{t}^{d}
$$

or after normalization, and dropping time subscripts,

$$
w n^{m d}+p r^{k} k^{m d} \leq v^{d}
$$

where $w n^{m d}$ the firm's normalized wage bill and $p r^{k} k^{m d}$ is the firm's normalized rental payments on capital, with normalized bank loans defined by $v^{d} \equiv V^{d} / Z$.

The first-order conditions to the firm's optimization problem can be written as follows:

$$
r^{k}\left(1+r^{l}\right)=F_{k^{m d}}
$$




$$
(w / p)\left(1+r^{l}\right)=F_{n^{m d}}
$$

Equations (26) and (27) represents the optimal marginal factor employment decisions of the firm. Given the financing constraint, the return to an additional unit of market capital, on the right hand side of equation (26), must equal the marginal cost, on the left-hand side of equation (26), that is adjusted for the cost of financing. Equation (27) is a similar efficiency condition for labor.

\section{The financial intermediary}

The financial sector is assumed to be competitive and represented by a single, aggregate financial intermediary that accepts deposits, issues bonds, receives reserves injections from the monetary authorities, and makes loans both to households and to firms. It maximizes profits (or net cash flows) period by period by choosing its balance sheet, or

$$
\max _{\left\{Z_{t}^{d}, L_{t}, D_{t}, B_{t}\right\}} \Pi_{t}^{c b}
$$

where: $Z_{t}^{d}$ is the bank's demand for per capita reserves, $L_{t}$ is the total volume of per capita bank loans, $D_{t}$ is the quantity of per capita bank deposits supplied to households, $B_{t}$ is the bank's supply of bonds, and $\Pi_{t}^{c b}$ is the bank's net cash flows, or period profits, given by:

$$
\Pi_{t}^{c b}=Z_{t}^{d}+\left(1+r_{t}^{l}\right) L_{t}-\left(1+r_{t}^{d}\right) D_{t}-\xi^{l} L_{t}-\xi^{d} D_{t}-\left(1+r^{b}\right) B_{t}, \quad \xi^{l}, \xi^{d}>0
$$

The parameters $\xi^{l}$ and $\xi^{d}$ represent the marginal cost of servicing loans and deposits.

Each period the bank must meet reserve requirements on deposit balances, or:

$$
Z_{t}^{d} \geq \zeta D_{t}^{d}, \quad \zeta \in(0,1)
$$

where $\zeta$ is the reserve requirement ratio, and satisfy its balance sheet constraint:

$$
Z_{t}^{d}+L_{t} \leq D_{t}+B_{t}
$$


Define the following normalized variables after dropping the time subscripts: $z^{d} \equiv Z^{d} / Z$, $l \equiv L / A, d \equiv D / Z$, and $b \equiv B / Z$. Then equations (30) and (31) become:

$$
z^{d} \geq \zeta d
$$

and

$$
z^{d}+l \leq d+b
$$

The optimal balance sheet choices must be consistent with the following interest rate spreads (after dropping time subscripts):

$$
\begin{gathered}
1+r^{d}+\xi^{d}=\zeta+(1-\zeta)\left(1+r^{b}\right) \\
r^{b}=r^{l}-\xi^{l}
\end{gathered}
$$

Equation (34) equates the marginal cost of funds to the bank between deposits and bonds. Equation (35) equates the marginal cost of acquiring, say, one dollar of funds raised by issuing bonds, with the return from lending out that dollar.

\section{Equilibrium}

To define an equilibrium for this economy, let the aggregate state vector be defined by $S \equiv\left[K^{h}, K^{m}, m, d, b\right]$, the set of aggregate decision rules be given by $\Omega^{h}(S) \equiv$ $\left[C^{a}(S), C^{m}(S), C^{h}(S), \tilde{n}^{m}(S), N^{h}(S), N^{l}(S), K^{h^{\prime}}(S), \tilde{k}^{m^{\prime}}(S), \tilde{m}^{d^{\prime}}(S), \tilde{d}^{\prime}(S), \tilde{b}^{\prime}(S), \tilde{x}(S)\right]$ and $\Omega^{a}(S) \equiv\left[k^{m d}(S), n^{m d}(S), z^{d}(S), l(S)\right]$, and the aggregate laws of motion that govern the evolution of the aggregate economy defined as $\Phi(S) \equiv\left[K^{h^{\prime}}(S), K^{m^{\prime}}(S), m^{\prime}(S), d^{\prime}(S)\right.$, $\left.b^{\prime}(S)\right]$.

A recursive competitive equilibrium is defined by the set of household decision rules, $\gamma(s)$, the set of aggregate decision rules, $\Omega^{h}(S)$ and $\Omega^{a}(S)$, and aggregate laws of motion, $\Phi(S)$, the aggregate pricing functions, $p(S), w(S), r^{d}(S), r^{l}(S), r^{b}(S)$, the monetary policy rule, equation (8), and the value function, $v(s)$, that are consistent with: 
(i) (household optimization): equations (16)-(21), given the constraints on: the consumption aggregation, equation (10), the payment system, equation (12), the home production technology, equation (13), the household's financing of gross investment in home capital, equation (14), and time, equation (15);

(ii) (firm optimization): equations (26) and (27), given the working capital financing constraint, equation (25);

(iii) (financial intermediary optimization): equations (34) and (35), given reserve requirements, equation (32), and the balance sheet constraint, equation (33);

(iv) (aggregate consistency conditions): $\gamma(s)=\Omega^{h}(S)$; and

(v) (equilibrium conditions): in the markets for: labor, $\tilde{n}^{m}=n^{m d} \equiv N^{m}$; market capital, $\tilde{k}^{m}=k^{m d} \equiv K^{m} ;$ money, $\tilde{m}^{d}=m$; deposits, $\tilde{d}^{d}=d$; bonds, $\tilde{b}^{d}=b$; and the following numbered equations for bank reserves, bank loans, and goods, respectively:

$$
\begin{gathered}
z^{d}(S)=1 \\
\tilde{x}(S)+v^{d}(S)=l(S) \\
C^{m}(S)+K^{h^{\prime}}(S)-(1-\delta) K^{h}+K^{m^{\prime}}(S)-(1-\delta) K^{m}=F\left[K^{m}, n^{m d}(S)\right]
\end{gathered}
$$

\section{Calibration of Alternative Steady-state Versions of the Model}

The theoretical model developed in the previous section can be thought to embed four different models with different sets of features relating to credit frictions that could affect the incidence and welfare costs of anticipated inflation. From the simplest version to the most complex, these models include: (1) cash-in-advance, with a financing constraint on working capital expenses for firms via direct lending from household to firms in a bond market; (2) a payment system that includes deposits as a medium of exchange, and a financial intermediary that engages in asset transformation and provides working capital 
loans to firms; (3) same as (2), but with households engaging in home production; and (4) same (3), but with households required to finance their gross investment in home capital with loans from the financial intermediary. This section describes the steady-state versions of these four models and the calibration procedures used for each, beginning with the full model, version (4), that is described in section II.

\section{Data}

With the exceptions noted below, the four models were calibrated using annual data from 1960-1998, where the initial date is chosen due to limitations on the availability of monetary data, and the latter date is due to limitations on the availability of capital stock data. For some of the calibrated values noted below, bank call report data on consumer loans and commercial and industrial (C\&I) loans were used. These time series begin in 1976. The information used to compute the ratio of bank to nonbank credit for working capital finance was taken from the Quarterly Financial Reports for Manufacturing Companies, 1980. The deposit rate data is taken from the Federal Reserve's estimate of a weighted-average rate of return on liquid bank deposit accounts (OMS rate) for 1973-1999. The capital stock data was taken from the Survey of Current Business, 1999. All other data were extracted from the Federal Reserve's FAME database.

\section{Steady-state version of the home production model}

The model described above consists of twenty-one equations, (10),(12)-(21),(25)-(27), and (32)-(38), that can be solved in the steady state for the following twenty-one variables: $C^{a}, C^{h}, C^{m}, N^{h}, N^{m}, N^{l}, K^{h}, K^{m}, p, w, r^{k}, r^{d}, r^{b}, r^{l}, m, d, b, \tilde{x}, v, l$ and $z^{d}$. The steady-state version of the model is given below:

$$
\begin{gathered}
C^{a}=C\left(C^{h}, C^{m}\right) \\
p C^{m}=G(m, d) \\
C^{h}=H\left(K^{h}, n^{h}\right)
\end{gathered}
$$




$$
\begin{aligned}
& p \delta K^{h}=\tilde{x} \\
& N^{m}+N^{h}+N^{l}=1 \\
& \beta\left[r^{k^{\prime}}+(1-\delta)\right]=1 \\
& {[1-\beta(1-\delta)]\left(1+r^{l}\right) H_{N^{h}}=\beta(w / p) H_{k^{h}}} \\
& G_{m}\left\{\left[U_{c^{a}} C_{c^{m}} / U_{n^{l}}\right](w / p)-1\right\}=\mu / \beta-1 \\
& G_{d^{d}}\left\{\left[U_{c^{a}} C_{c^{m}} / U_{n^{l}}\right](w / p)-1\right\}=\mu / \beta-\left(1+r^{d}\right) \\
& \beta\left(1+r^{b}\right)=\mu \\
& U_{n^{l}}=U_{c^{a}} C_{c^{h}} H_{n^{h}} \\
& w N^{m}+p r^{k} K^{m}=v \\
& r^{k}\left(1+r^{l}\right)=F_{k^{m}} \\
& (w / p)\left(1+r^{l}\right)=F_{n^{m}} \\
& z^{d}=\zeta d \\
& z^{d}+l=d+b \\
& 1+r^{d}+\xi^{d}=\zeta+(1-\zeta)\left(1+r^{b}\right) \\
& r^{b}=r^{l}-\xi^{l} \\
& z^{d}=1 \\
& \tilde{x}+v=l
\end{aligned}
$$




$$
C^{m}+\delta K^{h}+\delta K^{m}=F\left[K^{m}, N^{m}\right]
$$

To calibrate the model, functional forms have been selected for the utility function, $U$, the consumption aggregator, $C$, the payment system technology, $G$, home production, $H$, and market production, F. Following Behabib, Rogerson, and Wright (1991) and McGrattan, Rogerson, and Wright (1997), utility is assumed to be a (log-linear) function of leisure and an aggregation of home and market consumption.

$$
U\left(N^{l}, C^{a}\right)=\eta \ln N^{l}+\ln C^{a}, \quad \eta>0
$$

where the following CES aggregator function is used to obtain $C^{a}$.

$$
C\left(C^{h}, C^{m}\right)=\left[\gamma C^{m \theta}+(1-\gamma) C^{h^{\theta}}\right]^{1 / \theta}, \quad \gamma \in(0,1), \quad \theta>0
$$

The payment system technology is Cobb-Douglas in normalized money and deposits.

$$
G(m, d)=g_{0} m^{g_{1}} d^{\left(1-g_{1}\right)}, \quad g_{0}>0, \quad g_{1} \in(0,1)
$$

Home production is also characterized by a CES function, or constant elasticity of factor substitution between home capital and home production time.

$$
H\left(K^{h}, N^{h}\right)=\left[\alpha_{1} K^{h^{\lambda}}+\left(1-\alpha_{1}\right) N^{h^{\lambda}}\right]^{1 / \lambda}, \quad \alpha_{1} \in(0,1), \quad \lambda>0
$$

Market production is Cobb-Douglas in market capital and labor.

$$
F\left(K^{m}, N^{m}\right)=A\left(K^{m}\right)^{\alpha_{2}}\left(N^{m}\right)^{\left(1-\alpha_{2}\right)}, \quad A>0, \quad \alpha_{2} \in(0,1)
$$

In total, there are fourteen parameters in the model: $g_{0}, g_{1}, \theta, \gamma, \alpha_{1}, A, \alpha_{2}, \lambda, \delta, \beta, \eta, \zeta$, $\xi^{l}$, and $\xi^{d}$; in addition to the policy parameter describing the gross growth rate of bank reserves, $\mu$. Therefore, to calibrate the model, fifteen constraints are needed. To facilitate comparison with the literature on the welfare costs of inflation, a quarterly calibration is used. $^{3}$ In general, the procedure outlined in Cooley and Prescott (1995) is followed with

3 As noted by Cooley and Hansen (1989), the welfare costs can increase significantly when the length a "period" in the model increases. 
the exception of defining the capital stocks. In this model, market capital is defined as stocks of producer durables, structures, and inventories, and home capital is defined as the stocks of consumer durables and housing.

In accordance with this procedure and these definitions, the data support a market capital to quarterly output ratio of $K^{m} / y=5.177$, a factor share on market capital in market production of $\alpha_{2}=0.317$, and a ratio of home capital to market capital of $K^{h} / K^{m}=1.083$. The fraction of time allocated to market activity is set to $N^{m}=0.32$, and to home production is set to $N^{l}=0.25$, which are consistent with the survey data discussed by Juster and Stafford (1991). The two key home production parameters that determine the substitution elasticities between home and market consumption, $\theta$, and between capital and labor in home production, $\lambda$, are initially selected on the basis of point estimates obtained by McGrattan, Rogerson, and Wright (1997). They report two sets of estimates: $\theta=0.429, \lambda=0.0189$ and $\theta=0.326, \lambda=0.269$, where the latter are based on regressions using HP-filtered data. For the benchmark model, the following intermediate values are chosen: $\theta=0.385$ and $\lambda=0.2$. Sensitivity analysis is then performed over the ranges $\theta, \lambda \in[0.2,0.8]$. Finally, the scale parameter in production, $A$, is set to one.

From the financial data, total loans are defined to be the sum of consumer loans and C\&I loans in banks plus mortgages (on 1-to-4 family residences) plus nonbank sources of working capital finance, where the last of these is determined from the ratio of bank to nonbank sources of short-term lending to firms. Using this definition, the ratio of total transaction deposits (OCDs+DDAs) to total loans is $d / l=0.1855$. The currency-deposit ratio is $m / d=0.365$. In the model, the steady-state inflation rate is equal to the rate of growth of bank reserves. Since the distortions that the model is examining are due to inflation, the gross quarterly growth rate of bank reserves is set equal to $\mu=1.00995$ to correspond to the actual mean annual CPI inflation rate of 3.98 percent. It is noteworthy that this figure is very close to the actual annual growth rate of bank reserves, which is 3.61 percent. The reserve requirement ratio is set to the current value for transaction deposits of $\zeta=0.1$. The average deposit rate is $r^{d}=4.721$ percent, the average bond rate, taken to be the 90-day commercial paper rate, is $r^{b}=8.38$ percent, and the average bank loan rate, taken to be the prime lending rate, is $r^{l}=9.403$ percent, where all of 
these rates are annualized. The remaining parameter values for this model compute to: $g_{0}=3.246, g_{1}=0.455, \eta=0.669, \gamma=0.415, \beta=0.9892, \alpha_{1}=0.2763, \delta=0.0493, \xi^{s}=$ $0.0071, \xi^{l}=0.0026$. It is noted here that in choosing the point estimates for $\theta$ and $\lambda$ that are within the range reported by McGrattan, Rogerson, and Wright (1997), the calibrated values of $\gamma=0.415$ and $\alpha_{1}=0.2763$ are also close to their estimates of: $\gamma=0.414$ and $\alpha_{1}=0.206$ and $\gamma=0.412$ and $\alpha_{1}=0.140$.

\section{Alternative versions of the model}

In model version (3), bank financing of gross investment in home capital is not required. The steady-state version of the model given by equations (1.1) to (1.21) above is modified by deleting the financing constraint, equation (1.4), and setting $\tilde{x}=0$ in equation (1.20), implying that all intermediated loans are to firms for working capital expenses. The Euler equation (1.7) is also modified by deleting the term $\left(1+r^{l}\right)$ to remove the distortion associated with the financing constraint. It becomes:

$$
[1-\beta(1-\delta)] H_{n^{h}}=\beta(w / p) H_{k^{h}}
$$

The elimination of household financing requirements implies that total loans in the calibration needs to be redefined to exclude consumer loans and mortgages, which corresponds to $d / l=0.6438$. This modification necessitates changes for the following parameter values for version $(3): g_{0}=0.935, \eta=0.6683, \gamma=0.4203, \alpha_{1}=0.217$.

For version (2), home production is eliminated. This requires the following additional changes to the (1.1) to (1.21). Equations (1.3), (1.7), and (1.11) are dropped. The variable labeled $N^{h}$ is now set to zero, and the utility function is assumed to be log-linear in market

consumption and leisure, or $U\left(C^{m}, N^{l}\right)=\ln C^{m}+\eta \ln N^{l}, \quad \eta>0$. The Euler equations associated with $m^{\prime}$ and $d^{\prime}$, equations (1.8) and (1.9) become:

$$
\begin{gathered}
G_{m}\left\{\left[U_{c^{m}} / U_{n^{l}}\right](w / p)-1\right\}=\mu / \beta-1 \\
G_{d}\left\{\left[U_{c^{m}} / U_{n^{l}}\right](w / p)-1\right\}=\mu / \beta-\left(1+r^{d}\right)
\end{gathered}
$$


With the technology parameter for home production, $\alpha_{1}$, no longer appearing in the model, the set of parameters becomes: $g_{0}=1.896$ and $\eta=1.8737$, with $g_{1}, \beta, \alpha_{2}, A, \delta, \zeta, \xi^{d}, \xi^{l}$, and, of course, $\mu$ unchanged.

For version (1), the financial intermediary is eliminated and the model is a simple cashin-advance economy with a corporate bond market that firms use to finance working capital expenses. Relative to version (3), this model requires that equation (1.1) be replaced with the standard cash-in-advance constraint (in equilibrium):

$$
p C^{m}=1
$$

and the Euler equations $(1.8 \mathrm{v} 2)$ and $(1.9 \mathrm{v} 2)$ be replaced with a single Euler equation associated with $m^{\prime}$ since deposits $d$ are dropped from the model.

$$
\left[U_{c^{m}} / U_{n^{h}}\right](w / p)=\mu / \beta
$$

With households lending directly to firms, the volume of working capital loans, $v$, is replaced by the stock of bonds issued, $b$, and the firm's financing constraint is modified accordingly.

$$
w N^{m}+p r^{k} K^{m}=b
$$

In addition, the interest rate distortion in the first-order conditions relating to the firm's factor employment decisions is now the bond rate, $r^{b}$, rather than the bank loan rate, $r^{l}$.

$$
\begin{gathered}
r^{k}\left(1+r^{b}\right)=F_{K^{m}} \\
(w / p)\left(1+r^{b}\right)=F_{N^{m}}
\end{gathered}
$$

Finally, the portion of the model that describes the role of the financial intermediary is eliminated, and equations (1.15) through (1.20) are dropped. The parameter values for version (1) are: $\eta=1.876$, and $\beta, \alpha_{2}, A$, and $\delta$, all of which remain unchanged, as does $\mu$, which now represents the gross growth rate of the nominal money supply, $M^{\prime} / M$. 


\section{Results}

This section reports results on the incidence and welfare costs of inflation associated with each of the four versions of the model. These results are contrasted to illustrate the separate effects of credit market frictions, the role played by the financial intermediary, and home production on the models' predictions of the consequences of higher steady-state inflation. Of particular interest is how inflation affects the observable quantities of market employment and market output, and their relationship to welfare. Version (1) illustrates that the working capital financing constraint on firms significantly magnifies the adverse consequences that inflation has on employment and output, and results in a substantial increase in the welfare costs of inflation. In version (2), the introduction of a financial intermediary into the model is shown to mitigate these effects, owing to the fact that much of the endogenous adjustment to higher inflation takes place in the payments system and the financial markets rather than in the labor market. Version (3) describes how the inclusion of home production in the model induces much sharper declines in employment and output and much greater welfare losses as inflation increases than would otherwise be the case. In version (4), the financing requirement for gross investment in home capital is shown to mitigate the effect on employment and output, since inflation acts in part as a tax on home production, thus providing a disincentive to pull resources from the market for use at home. However, welfare unambiguously declines as a result of the financing constraint.

\section{Cash-in-advance model with a firm financing constraint}

Table 1 reports the steady-state results from version (1) of the model for the effects that inflation has on employment, output, and welfare. The various levels of inflation are listed in the first column, where it is seen to range from -2 percent to 20 percent, with the calibrated value of 3.98 percent used for each subsequent version of the model. Version (1) is the cash-in-advance model with a financing constraint imposed on firms, where the inflation tax directly distorts two decisions. Households' nominal consumption purchases are taxed, and they therefore choose to reduce consumption. This induces a loss of utility 
that the household can partially offset by increasing leisure. Consequently, employment and output fall. This is exactly the distortion examined by Cooley and Hansen (1989). The second effect is to raise the marginal cost to firms of employing both capital and labor due to the financing constraint, thus requiring a higher marginal product from each factor, which again leads to a decline in employment and output. These joint effects are illustrated in the second and third columns of Table 1, where percent changes in market employment and market output relative to their calibrated steady-state values are tabulated. By way of comparison, the reductions in employment and output associated with a change from stable prices (zero inflation) to a ten percent inflation rate, as reported in the bottom row of Table 1, are 3.92 percent and 5.06 percent respectively. These numbers are significantly larger than those reported in Cooley and Hansen (1989, Table 2), where the employment decline is 2.35 percent and the fall in output is 2.45 percent. Welfare losses are reported in the last column. They imply a welfare loss measured to be equivalent to a 0.803 percent decline in steady-state consumption. This number is significantly larger than the 0.376 percent figure reported in Cooley and Hansen (1989). These results illustrate the importance of the firm's financing constraint on the distortionary effects of anticipated inflation. Note that in order to facilitate comparison, the results of conducting this exercise of increasing the inflation rate from zero to ten percent for each version of the model are collected in the Summary Table (Table 7).

\section{[Insert Table 1]}

\section{The role of the financial intermediary}

In version (2), a financial intermediary is added to the model. In this case, the same distortionary channels described above are operative. The important difference is that in version (2), the financial intermediary engages in asset transformation by creating deposit accounts with a high liquidity value and uses the proceeds to finance in part the working capital loans to firms. In this case, the distortion in the households' consumption-savings decision is mitigated somewhat by an endogenous adjustment in the payments system, whereby households switch the composition of their media of exchange away from money 
and toward deposits, with the interest income received on their deposit accounts partially insulating them from inflation. In response, the financial intermediary relies more heavily on deposits versus bonds as a source of funds. These results are illustrated in Table 2. In column 5, the shift toward deposits and away from money as inflation increases is evident in the falling currency-deposit ratio as you move down the table. Again, use the zero to ten percent inflation regimes for comparison, with the changes displayed on the bottom row of the table, and repeated in the Summary Table (Table 7). In comparison with results from version (1), columns 2 and 3 illustrate that there are lesser adverse effects on market employment, which now falls by 2.89 percent, and market output, which declines by 4.03 percent in response to an increase of inflation from zero to ten percent. The welfare losses are also seen to be smaller, where in column 4 they correspond to a reduction in steadystate consumption of 0.662 percent. Therefore, explicitly accounting for the valued asset transformation activity performed by the financial intermediary can reduce the welfare costs of inflation on the order of 20 percent. ${ }^{4}$

\section{[Insert Table 2]}

\section{Home production.}

The next comparison is between version (2) and version (3), where the latter adds a home production technology given by equation (43) with preferences described by equations (40) and (41). The distortion in the firm's factor employment decisions due to the effect of inflation on the financing constraint remains. Likewise, as inflation increases, households adjust their composition of the media of exchange in order to increase the velocity of money. However, when households also choose to avoid the inflation tax that is imposed on their nominal consumption purchases, they do not simply withdraw labor services to increase leisure, but they may also choose to reallocate a portion of their non-market time toward increasing the production of home consumption goods. An added complication is that while they would like to pull resources out of the market since market activities are

\footnotetext{
4 A similar result is also obtained in Marquis (1999).
} 
being taxed, they are constrained somewhat by the need to acquire home capital for home production, and this home capital is produced in the market.

Table 3 illustrates the optimal capital and labor resource allocation decisions in response to higher steady-state inflation. Progressing down the table in columns 2 through 4, higher inflation is seen to induce a reallocation of time away from employment in the market and toward both homework and leisure, with a greater increase in the former. The disproportionate increase in homework is attributable in part to the fact that market output has declined, as indicated in column 5, and this reduces the production of both market and home capital. Thus, the increase in homework is partly offsetting the decline in home capital in home production, which has consequently become more labor-intensive. However, as indicated in columns 6 through 8, there is a greater decline in market capital than in home capital, such that the ratio of home to market capital increases monotonically with inflation.

\section{[Insert Table 3]}

Quantitatively, the declines in the observables of employment and output that are illustrated in Table 3 are much higher than those reported in Table 2 for the version of the model that did not explicitly account for home production. Once again using the zero to ten percent comparison, the bottom row of Table 3, and repeated in the Summary Table (Table 7), indicates that the addition of the home production sector to the model increases the predicted employment decline to 3.99 percent from 2.89 percent, while output is projected to decline by 5.13 percent versus 4.03 percent.

Table 4 portrays how the responses to inflation reduce welfare. From columns 2 through 4, it is evident that higher inflation causes the household to experience a utility loss from the decline in market consumption, that is partially offset by an increase in home consumption. However, on balance the household experiences less utility from consumption over all, as indicated in column 4, and more utility from leisure, column 5, with the loss in consumption dominating and welfare declining, column 6. Quantitatively, this decline in welfare is much greater than in version (2) where there was no home production sector. From the bottom row of the table [and repeated in the Summary Table (Table 7)], the 
increase of inflation from zero to ten percent is seen to cause welfare to fall by 1.545 percent, which is more than double the 0.662 percent decline in version (2).

\section{[Insert Table 4]}

\section{Home production with a household financing constraint.}

The additional effect that forcing households to finance their gross investment in home capital with bank loans is examined by comparing versions (3) and (4) of the model. The distortions associated with higher inflation are identical in the two versions, except that the marginal cost of acquiring home capital is greater in version (4). This effectively taxes home production, and tends to divert resources away from that activity. Refer to Table 5. As in version (3), columns 2 through 4 indicate that employment falls while homework and leisure increase with inflation. However, when compared with Table 3, this decline in employment is somewhat muted, implying that there is less additional nonmarket time for the household to allocate between homework and leisure. Even so, relative to version 3 , households choose to increase leisure to a greater extent, column 3, thus lessening the increase in homework, column 2. The rationale for this allocation of nonmarket time is that inflation increases the cost of financing investment in home capital, thereby requiring a higher marginal product of capital, which in turn results in a much lower steady-state stock of home capital, which is seen by comparing columns 6 in Tables 3 and 5, thus reducing the marginal product of homework.

\section{[Insert Table 5]}

From Table 6, it is evident that households respond to higher inflation by reducing market consumption, column 2, much less when the home financing constraint is present. As a consequence, the determinants of household utility (welfare) is shifting away from home consumption, and toward market consumption and leisure as a result of this credit friction. Unlike version (3), this effect is strong enough under this calibration to induce an outright decline in home production, column 2, and this decline more than offsets in 
the contribution of a lesser decline in higher market consumption, column 3 , in the overall aggregate consumption measure, column 4.

\section{[Insert Table 6]}

To summarize these results quantitatively, the observables of employment and market output are less adversely affected by inflation in the home production model when the household financing constraint is present in the model. For the zero to ten percent inflation case, market employment falls by 3.78 percent, as shown in column 2 of Table 6 , and repeated in the Summary Table (Table 7), and output declines by 4.91 percent. However, the welfare losses are noticeably greater, with the welfare measure corresponding to a 1.921 percent reduction in consumption, or a 24 percent increase over version (3).

\section{[Insert Table 7]}

\section{Sensitivity analysis with respect to the home production parameters.}

There are two key parameters in the home production sector that could significantly affect the household resource allocation decisions. One is $\theta$ in the consumption aggregator function that determines the elasticity of substitution between home and market consumption, and the second is $\lambda$ in the home production technology that determines the elasticity of substitution between in home capital and homework. Sensitivity analysis is conducted on version (4) of the model for the range of values for $\theta, \lambda \in[0.2,0.8]$, with the results for percent changes in employment and output, along with the welfare costs, associated with an increase of the inflation rate from zero to ten percent, tabulated in Table 8.

\section{[Insert Table 8]}

In choosing $\theta$, the calibration of the model yields a value for $\gamma$, the share parameter in the consumption aggregator. Similarly, $\lambda$ and $\alpha_{1}$ cannot be separately chosen. Higher values of $\theta$ correspond to higher values of $\gamma$, while higher values of $\lambda$ coincide with lower values of $\alpha_{1}$. By observing the results in any given column in Table 8, it is evident that the elasticity of substitution between home consumption and market consumption has a greater 
effect on the employment and output responses to inflation than on the welfare losses. For example, from column 1, raising $\theta$ from the benchmark value of $0.385(\gamma=0.415)$ to 0.8 $(\gamma=0.482)$ amplifies the employment decline from 3.78 percent to 5.43 percent, while the output decline increases from 4.91 percent to 6.56 percent. However, because of the high degree of substitutability between home and market consumption in their determination of household utility, the welfare losses rise only from 1.921 percent to 1.944 percent.

By contrast, as can be seen from any one row in Table 8, the elasticity of substitution between home capital and homework in home production has a very large effect not only on employment and output, but also on welfare. From the second row of models, a comparison of the results obtained from the benchmark model in the first column with $\lambda=0.2\left(\alpha_{1}=\right.$ 0.276) and the calibration of the model with the higher elasticity of substitution [used by Greenwood and Hercowitz, (1991)] in column five of $\lambda=0.8\left(\alpha_{1}=0.069\right)$, there are sharp declines in employment, from 3.78 percent to 9.41 percent, and in output, from 4.91 percent to 10.53 percent. The welfare costs are seen to rise from 1.921 percent reduction in market consumption to 4.979 percent, which is approximately a 150 percent increase. In summary, these results imply that if either the elasticity of substitution in consumption or the elasticity of substitution in home production are higher than the estimates reported in McGrattan, Rogerson, and Wright (1997), then the welfare costs of inflation will rise. However, the more critical parameter is related to production rather than to preferences.

\section{Conclusions}

The early literature on the welfare costs of inflation concluded that these costs are significant, but modest when the only distortion is through a payment system constraint such as cash-in-advance, where financial assets alone are used to facilitate transactions. One purpose of this paper is to examine how these welfare costs are affected by an additional financial market friction in the form of a financing constraint imposed on firms who must borrow to finance their working capital expenses, and where those loans must be repaid with current sales revenues. The model suggests that this can significantly increase the welfare costs of inflation. However, when explicitly modeling financial intermediaries, who perform an economic function of valued asset transformation through which they create 
liquid interest-bearing deposit accounts and use the proceeds to finance, in part, the working capital loans to firms, the welfare losses are somewhat reduced. The lower welfare losses owe to the fact that households can adjust their media of exchange in response to higher inflation away from currency and toward interest-bearing deposit accounts and thereby partially insulate themselves from the inflation tax. This endogenous response in the households' means of payment, in turn, mitigates the distortionary effect on the households' factor supply decisions.

Inflation taxes market activity. This tax therefore induces households to withhold resources from the market and engage them in economic activity at home. Explicitly modeling non-market activity in a home production setting exacerbates the steady-state declines in employment and output caused by inflation, and raises the corresponding welfare costs. The magnitude of these responses depends crucially on the elasticity of substitution between home capital and homework in home production, where the employment and output declines and the welfare losses all rise as this elasticity increases. Nonetheless, even using the relatively low value consistent with the point estimates reported by McGrattan, Rogerson, and Wright (1997), the results suggest that explicitly accounting for home production activities significantly amplifies the employment and output declines induced by inflation, and dramatically raises the welfare costs of inflation. Adding a financing constraint on the household's gross investment in home capital renders the market employment and market output less distorted in the model due to an increase in inflation, as resources tend to move back into the market, but nonetheless raises welfare costs further. These results imply that inflation may be more costly than previously thought. 


\section{References}

Benhabib, Jesse, Richard Rogerson, and Randall Wright. (1991) "Homework in Macroeconomics: Household Production and Aggregate Fluctuations," Journal of Political Economy, vol. 99: 1166-118.

Cooley, Thomas F. and Gary D. Hansen. (1989) "The Inflation Tax in a Real Business Cycle Model," American Economic Review, vol. 79, no. 4, September: 733-749.

Cooley, Thomas F. and Gary D. Hansen. (1991) "The Welfare Costs of Moderate Inflations," Journal of Money, Credit and Banking, vol. 23, no. 3, August, Part 2: 483-503.

Cooley, Thomas F. and Edward C. Prescott. (1995) "Economic Growth and Business Cycles," in Frontiers in Business Cycle Research, ed. by Thomas F. Cooley, (Princeton University Press: Princeton): 1-38.

Chang, Wen-Ya and Ching-Chong Lai. (2000) "Anticipated Inflation in a Monetary Economy with Endogenous Growth," Economica, vol. 67, no. 267, August: 399-418.

DeGregorio, J. (1993) "Inflation, Taxation, and Long-run Growth," Journal of Monetary Economics, vol. 31: 271-298.

Einarsson, Tor and Milton H. Marquis. (1999) "Transitional and Steady-state Costs of Disinflation When Growth is Endogenous," Economica, vol. 66, no. 264, November: 489472.

Gomme, Paul. (1993) "Money and Growth Revisited: Measuring the Costs of Inflation in an Endogenous Growth Model," Journal of Monetary Economics, vol. 32, no. 1, August: $51-77$.

Greenwood, Jeremy and Zvi Hercowitz. (1991) "The Allocation of Capital and Time over the Business Cycle," Journal of Political Economy, vol. 99: 1188-1214.

Ireland, Peter N. (1994) "Money and Growth Revisited: An Alternative Approach," American Economic Review, vol. 84, no. 1, March: 47-65.

Juster, F. Thomas and Frank P. Stafford (1991) "The Allocation of Time: Empirical Findings, Behavioral Models, and Problems of Measurement," Journal of Economic Literature, vol. 29, June: 471-522.

Lucas, Robert E., Jr. (1988) "On the Mechanics of Economic Development," Journal of Monetary Economics, vol. 22, no. 1, August: 3-42.

Marquis, Milton H. (1999) "The Joint and Several Effects of Liquidity Constraints, Financing Constraints, and Financial Intermediation on the Welfare Costs of Inflation," 
Monetary and Economic Studies, vol. 17, Institute for Monetary and Economic Studies, Bank of Japan: 1-20.

Marquis, Milton H. and Kevin L. Reffett. (1992) "Capital in the Payments System," Economica, vol. 59, no. 325, August: 351-364.

Marquis, Milton H. and Kevin L. Reffett. (1994) "New Technology Spillovers into the Payment System," Economic Journal, vol. 104 : 1123-1138.

Marquis, Milton H. and Kevin L. Reffett. (1995) "The Inflation Tax in a Convex Model of Equilibrium Growth," Economica, vol. 62: 109-121.

McGrattan, Ellen, Richard Rogerson, and Randall Wright. (1997) "An Equilibrium Model of the Business Cycle with Household Production and Fiscal Policy,' International Economic Review, vol. 38, no. 2, May: 267-290.

Romer, Paul M. (1990) "Endogenous Technological Change," Journal of Political Economy, vol. 98, October: S71-S102.

Stockman, Alan C. (1991) "Anticipated Inflation and the Capital Stock in a Cash-inAdvance Model," Journal of Monetary Economics, vol. 8: 534-44.

Uzawa, H. (1965) "Optimal Technical Change in an Aggregative Model of Economic Growth," International Economic Review, vol. 6: 18-31.

Wang, P. and C.K. Yip. (1992) "Alternative Approaches to Money and Growth," Journal of Money, Credit and Banking, vol. 24: 553-562. 
Table 1

VERSION 1: CASH-IN-ADVANCE, WITH FIRM FINANCING CONSTRAINT

\begin{tabular}{cccc}
\hline $\begin{array}{c}\text { Inflation } \\
(\%, \text { annualized })\end{array}$ & $\begin{array}{c}\text { Employment } \\
----(\% \text { change relative to steady-state })----\end{array}$ & $\begin{array}{c}\text { Output } \\
\text { Welfare Losses }\end{array}$ \\
\hline & & & -0.427 \\
-2.00 & 2.393 & 3.104 & -0.361 \\
-1.00 & 1.987 & 2.576 & -0.293 \\
0.00 & 1.584 & 2.052 & 0.000 \\
3.98 & 0.000 & 0.000 & 0.510 \\
10.00 & -2.337 & -3.005 & 1.524 \\
20.00 & -6.065 & -7.745 & 0.803 \\
\hline
\end{tabular}


Table 2

VERSION 2: ADDITION OF THE FINANCIAL INTERMEDIARY

\begin{tabular}{ccccc}
\hline $\begin{array}{c}\text { Inflation } \\
\text { \%, annualized })\end{array}$ & $\begin{array}{c}\text { Employment } \\
--(\% \text { change relative to steady-state })--\end{array}$ & $\begin{array}{c}\text { Output } \\
\text { Currency/ } \\
\text { Deposits }\end{array}$ \\
\hline-2.00 & 1.833 & 2.538 & -0.372 & 1.094 \\
-1.00 & 1.506 & 2.090 & -0.312 & 0.788 \\
0.00 & 1.191 & 1.656 & -0.251 & 0.625 \\
3.98 & 0.000 & 0.000 & 0.000 & 0.365 \\
10.00 & -1.703 & -2.374 & 0.411 & 0.247 \\
20.00 & -4.385 & -6.091 & 1.180 & 0.180 \\
\hline \multirow{2}{*}{0 to $10 \%$} & -2.894 & -4.030 & 0.662 & \\
\end{tabular}


Table 3

VERSION 3: HOME PRODUCTION: RESOURCE ALLOCATIONS

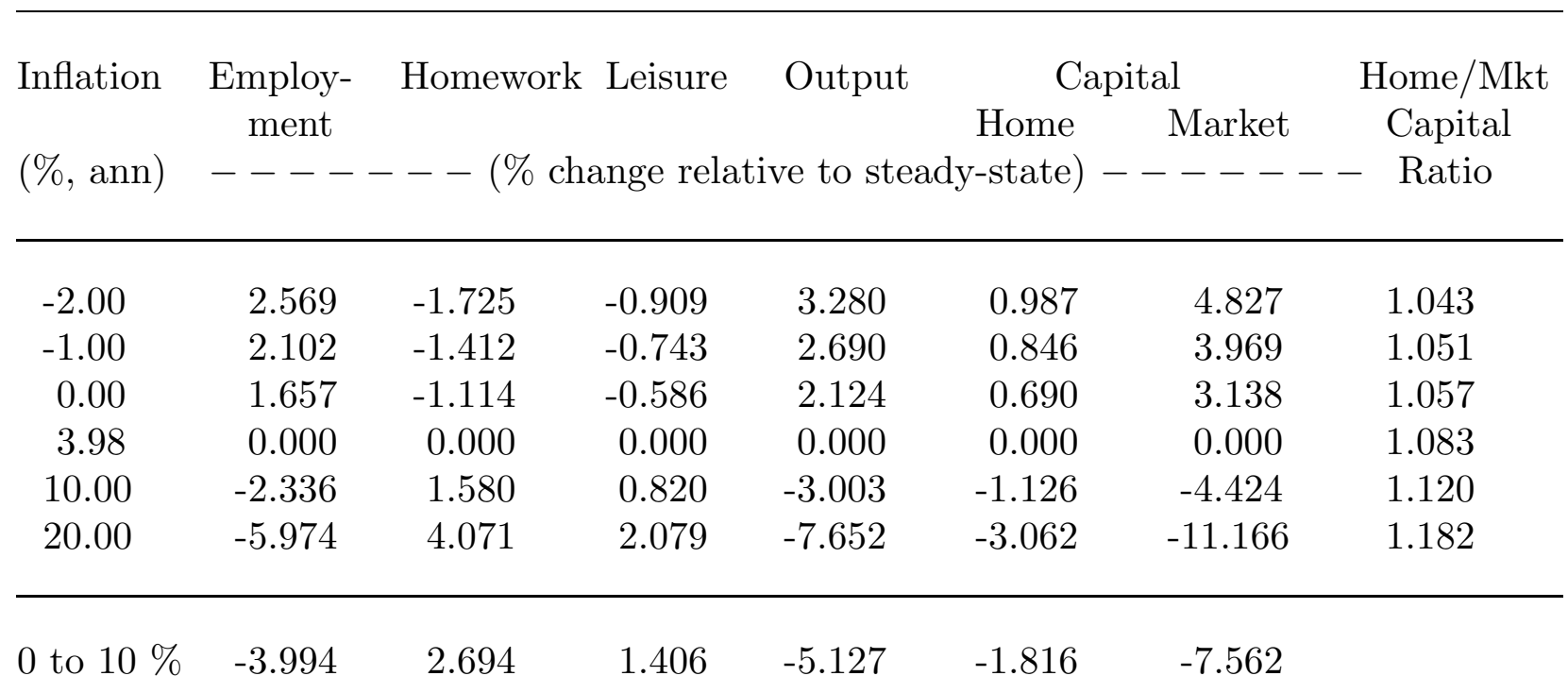


Table 4

VERSION 3: HOME PRODUCTION: DETERMINANTS OF WELFARE

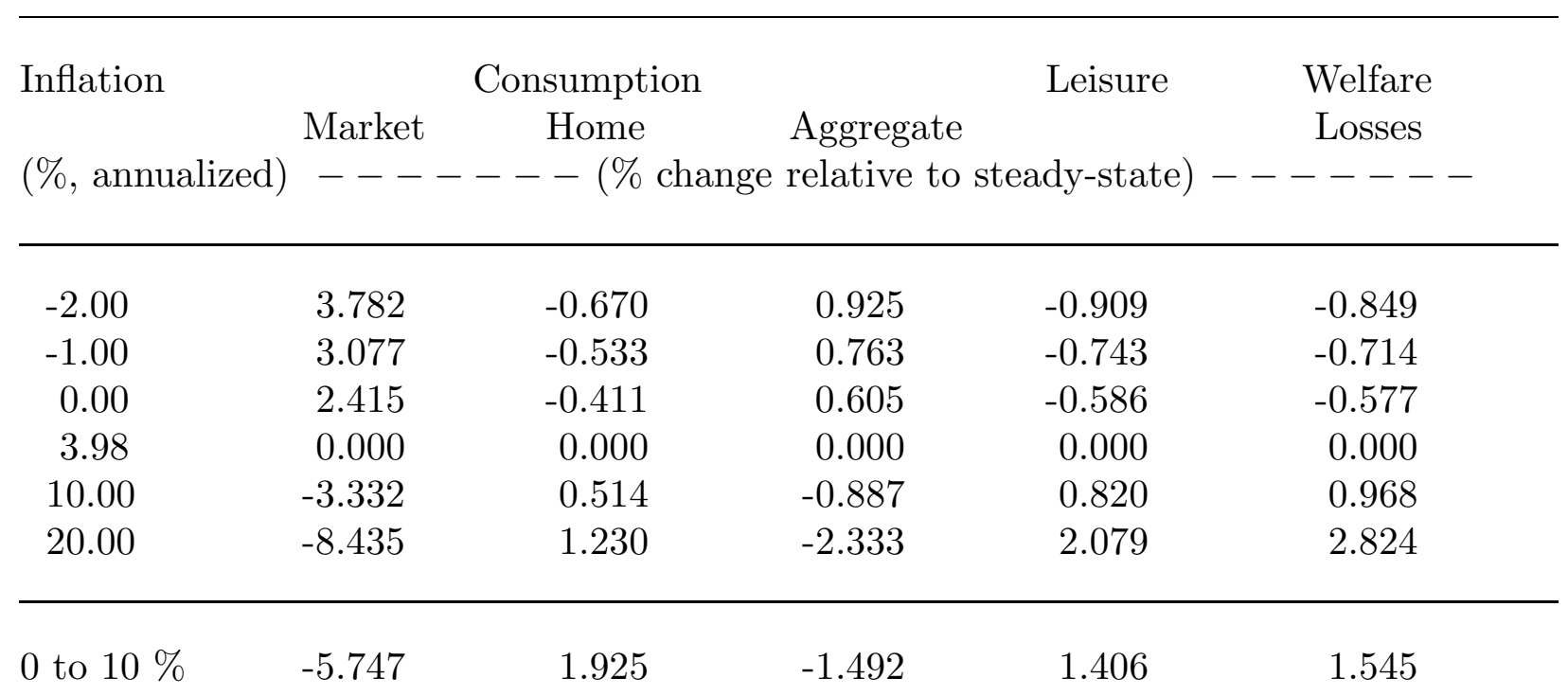


Table 5

VERSION 4: HOME PRODUCTION/HOUSEHOLD FINANCING CONSTRAINT: RESOURCE ALLOCATIONS

\begin{tabular}{|c|c|c|c|c|c|c|c|}
\hline \multirow{3}{*}{$\begin{array}{l}\text { Inflation } \\
(\%, \text { ann })\end{array}$} & \multirow{2}{*}{$\begin{array}{c}\text { Employ- } \\
\text { ment }\end{array}$} & \multirow[t]{2}{*}{ Homework } & \multirow[t]{2}{*}{ Leisure } & \multirow[t]{2}{*}{ Output } & \multicolumn{2}{|c|}{ Capital } & \multirow{2}{*}{$\begin{array}{c}\text { Home/Mkt } \\
\text { Capital }\end{array}$} \\
\hline & & & & & Home & Market & \\
\hline & ---- & $--(\%$ cha & ange rela & ive to stea & $y$-state) & ----- & - Ratio \\
\hline-2.00 & 2.342 & -1.486 & -0.879 & 3.051 & 3.133 & 4.595 & 1.068 \\
\hline-1.00 & 1.936 & -1.229 & -0.727 & 2.523 & 2.608 & 3.800 & 1.071 \\
\hline 0.00 & 1.539 & -0.977 & -0.577 & 2.005 & 2.082 & 3.018 & 1.073 \\
\hline 3.98 & 0.000 & 0.000 & 0.000 & 0.000 & 0.000 & 0.000 & 1.083 \\
\hline 10.00 & -2.242 & 1.433 & 0.835 & -2.909 & -3.074 & -4.331 & 1.097 \\
\hline 20.00 & -5.799 & 3.733 & 2.146 & -7.480 & -7.951 & -11.008 & 1.120 \\
\hline 0 to $10 \%$ & -3.780 & 2.410 & 1.412 & -4.914 & -5.156 & -7.349 & \\
\hline
\end{tabular}


Table 6

VERSION 4: HOME PRODUCTION/HOUSEHOLD FINANCING CONSTRAINT: DETERMINANTS OF WELFARE

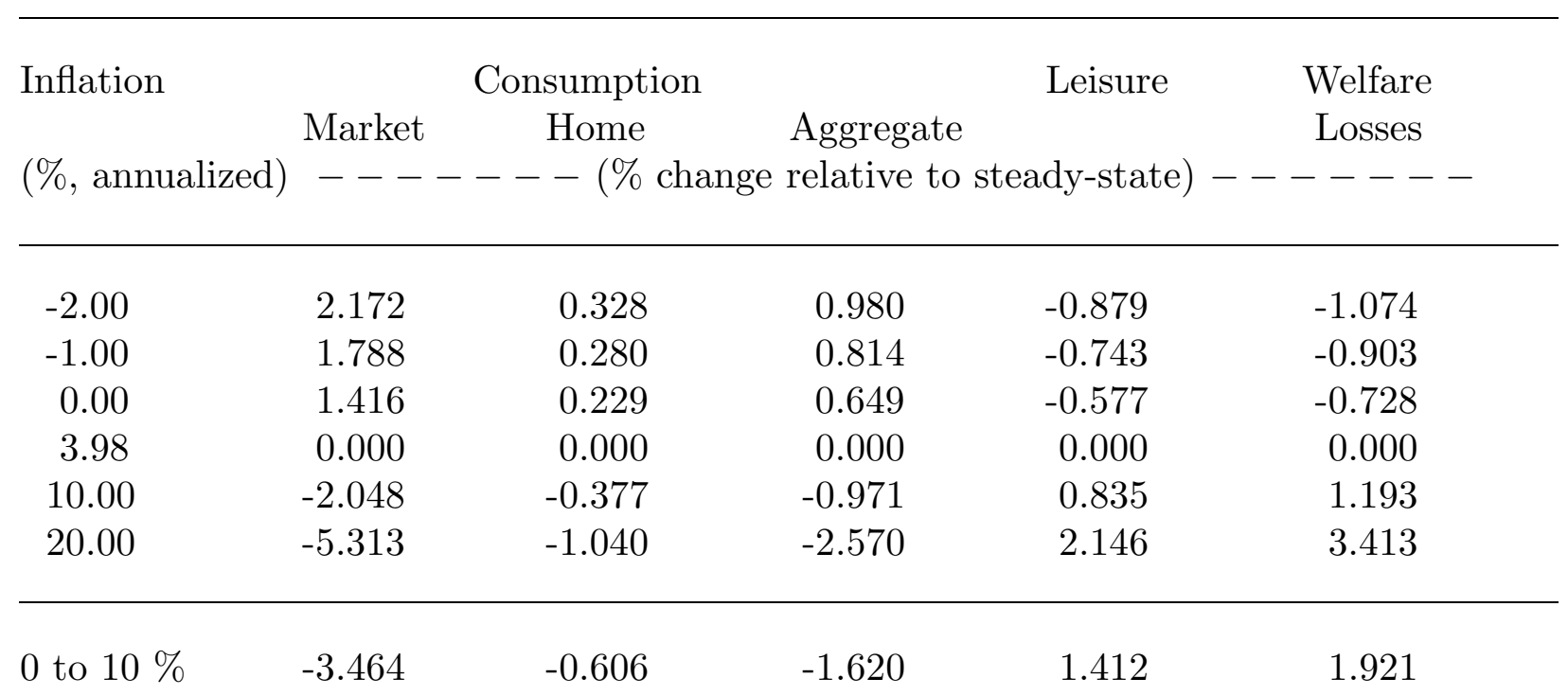




\section{Table 7}

\section{SUMMARY TABLE OF STEADY-STATE RESULTS}

$\%$ change associated with an increase in steady-state inflation from $0 \%$ to $10 \%$

\begin{tabular}{lccc}
\hline & Employment & Output & Welfare Losses \\
\hline $\begin{array}{l}\text { Cooley-Hansen (1989), CIA Model } \\
\text { VERSION 1: Add Firm }\end{array}$ & -2.35 & -2.45 & 0.376 \\
Financing Constraint & -3.92 & -5.06 & 0.803 \\
VERSION 2: Add Financial & & & \\
Intermediary & -2.89 & -4.03 & 0.662 \\
VERSION 3: Add Home & -3.99 & -5.13 & 1.545 \\
Production & & & \\
VERSION 4: Add Household & -3.78 & -4.91 & 1.921 \\
Financing Constraint & & & \\
\hline
\end{tabular}


Table 8

SENSITIVITY ANALYSIS ON HOME PRODUCTION PARAMATERS $\lambda$ AND $\theta$

$\%$ change associated with an increase in steady-state inflation from $0 \%$ to $10 \%$

\begin{tabular}{|c|c|c|c|c|c|}
\hline \multicolumn{6}{|c|}{$\lambda\left(\alpha_{1}\right)$} \\
\hline & $0.200(0.276)$ & $0.385(0.187)$ & $0.500(0.144)$ & $0.667(0.097)$ & $0.800(0.069)$ \\
\hline \multicolumn{6}{|l|}{$\theta=0.200$} \\
\hline$\gamma$ & 0.385 & 0.380 & 0.375 & 0.371 & 0.368 \\
\hline welfare losses & 1.918 & 2.226 & 2.532 & 3.348 & 4.975 \\
\hline$N^{m}$ declines & 3.596 & 4.164 & 4.728 & 6.232 & 9.222 \\
\hline$y$ declines & 4.730 & 5.297 & 5.860 & 7.361 & 10.344 \\
\hline \multicolumn{6}{|l|}{$\theta=0.385$} \\
\hline$\gamma$ & 0.415 & 0.402 & 0.395 & 0.386 & 0.381 \\
\hline welfare losses & 1.921 & 2.229 & 2.535 & 3.352 & 4.979 \\
\hline$N^{m}$ declines & 3.780 & 4.349 & 4.913 & 6.418 & 9.412 \\
\hline$y$ declines & 4.914 & 5.581 & 6.044 & 7.547 & 10.533 \\
\hline \multicolumn{6}{|l|}{$\theta=0.500$} \\
\hline$\gamma$ & 0.433 & 0.416 & 0.407 & 0.396 & 0.388 \\
\hline welfare losses & 1.923 & 2.231 & 2.538 & 3.356 & 4.985 \\
\hline$N^{m}$ declines & 3.963 & 4.540 & 5.097 & 6.604 & 9.599 \\
\hline$y$ declines & 5.096 & 5.664 & 6.228 & 7.732 & 10.721 \\
\hline \multicolumn{6}{|l|}{$\theta=0.667$} \\
\hline$\gamma$ & 0.460 & 0.437 & 0.425 & 0.410 & 0.400 \\
\hline welfare losses & 1.930 & 2.239 & 2.547 & 3.368 & 5.004 \\
\hline$N^{m}$ declines & 4.451 & 5.022 & 5.588 & 7.099 & 10.103 \\
\hline$y$ declines & 5.583 & 6.152 & 6.717 & 8.226 & 11.223 \\
\hline \multicolumn{6}{|l|}{$\theta=0.800$} \\
\hline$\gamma$ & 0.482 & 0.455 & 0.440 & 0.421 & 0.409 \\
\hline welfare losses & 1.944 & 2.257 & 2.567 & 3.395 & 5.045 \\
\hline$N^{m}$ declines & 5.426 & 5.999 & 6.569 & 8.087 & 11.106 \\
\hline$y$ declines & 6.557 & 7.128 & 7.696 & 9.221 & 12.224 \\
\hline
\end{tabular}

